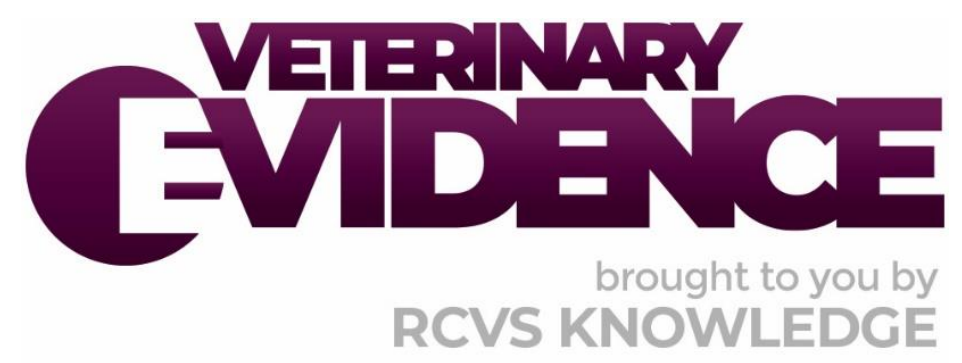

\title{
In female dogs undergoing elective neutering is ovariectomy or ovariohysterectomy superior?
}

\author{
A Knowledge Summary by
}

Catrina Pennington BVM\&S MRCVS ${ }^{1 *}$

\footnotetext{
1 The Royal Veterinary College, Royal College Street, London, NW1 OTU

Corresponding Author (trinpennington@gmail.com)
}

ISSN: 2396-9776

Published: 04 Jun 2020

in: Vol 5, Issue 2

DOI: $10.18849 / V E . V 512.303$

Reviewed by: Malcolm Ness (BVetMed CertSAO DipECVS

FRCVS) and Theophanes Liatis (DVM MRCVS) 


\section{KNOWLEDGE SUMMARY}

\section{PICO question}

In female dogs undergoing elective neutering via midline coeliotomy is ovariectomy superior to ovariohysterectomy in terms of anaesthetic duration, incision length, complications and postoperative pain?

\section{Clinical bottom line}

\section{Category of research question}

Treatment

\section{The number and type of study designs reviewed}

The number and type of study designs that were critically appraised were four prospective clinical trials (Peeters et al., 2011; Lee at al., 2013; Harris et al., 2013; and Tallant et al., 2016) and a retrospective cohort study (Okkens et al., 1997)

\section{Strength of evidence}

Critical appraisal of the selected papers meeting the inclusion criteria collectively provide weak evidence in terms of their experimental design and implementation

\section{Outcomes reported}

Okkens et al. (1997) found no occurrence of pyometra/endometritis in 135 dogs receiving ovariectomy (OVE) or ovariohysterectomy (OVH) over an 8-11 year follow-up period. This study also reported no significant difference in long-term postoperative complications in either group.

Of the four prospective clinical trials one (Harris et al., 2013) had final year vet students perform the surgeries. This study found no difference in incision length, surgical time or incidence of intra-operative complications between techniques. However the relevance of this study to procedures performed by qualified veterinary surgeons is questionable.

The remaining papers all evaluated incision length, surgical time and postoperative pain after surgeries performed by experienced vets. All three found mean incision length was shorter in the OVE group and two (Lee et al., 2013; and Tallant et al., 2016) found that surgical duration was shorter in the OVE group. Only one paper (Lee et al., 2013) revealed a significant difference in pain scoring between groups, with the OVE group having lower scores at 1, 2, 4 and 6 hours post-surgery. Lee at al. (2013) and Tallant et al. (2016) also recorded intra-operative complications, however none were noted in either group

\section{Conclusion}

In view of the strength of evidence and the outcomes from the studies the following conclusion is made; whilst the evidence does suggest OVE may be associated with some modest improvement in surgical time and incision length, due to the small sample sizes and varying techniques used, further studies are required before definitive conclusions can be made.

There is currently insufficient evidence to determine if there is a difference in complication rates or postoperative pain between procedures.

\section{How to apply this evidence in practice}

The application of evidence into practice should take into account multiple factors, not limited to: individual clinical expertise, patient's circumstances and owners' values, country, location or clinic where you work, the individual case in front of you, the availability of therapies and resources.

Knowledge Summaries are a resource to help reinforce or inform decision-making. They do not override the responsibility or judgement of the practitioner to do what is best for the animal in their care. 


\section{Clinical Scenario}

An 11-month-old, female entire crossbreed dog presents for elective neutering. You discuss surgical techniques with the client. You are confident at performing both ovariectomy and ovariohysterectomy via midline coeliotomy. Other techniques, including minimally invasive surgery and surgery through a flank incision, are not locally available or financially feasible and so are not considered.

When considering anaesthetic duration, incision length, complication rate and postoperative pain, what evidence is there to suggest OVE is superior to OVH or vice versa?

\section{The evidence}

From the literature reviewed here there is some evidence to suggest that when performed by an experienced veterinary surgeon OVE is associated with a shorter incision length and reduced surgical time compared to $\mathrm{OVH}$. However the studies reviewed differ markedly in case selection, technique and study objectives. The sample sizes are typically small and the experience of the operating veterinary surgeons may not accurately reflect an 'average' general practitioner. Additionally the differences in between procedures reported may not be clinically significant.

There is convincing evidence that, when properly performed, OVE is not associated with a risk of pyometra. There is currently insufficient evidence to determine if there is a difference in postoperative pain following OVH compared to OVE. No papers reported an improvement in any outcome with OVH compared to OVE.

In conclusion, whilst the evidence does suggest OVE may be associated with some modest improvement in surgical time and incision length, further studies are required before definitive conclusions can be made.

\section{Summary of the evidence}

\begin{tabular}{|c|c|}
\hline \multicolumn{2}{|l|}{ Harris et al. (2013) } \\
\hline Population: & $\begin{array}{l}\text { Female dogs of various breeds presented to a British veterinary } \\
\text { teaching hospital for elective neutering. Age range } 6-120 \text { months. } \\
\text { Weight range } 2.9-51.5 \mathrm{~kg} \text {. Dogs were excluded from recruitment if } \\
\text { there were signs of pregnancy, oestrus, pseudopregnancy or ill } \\
\text { health on clinical examination. Dogs were excluded at the time of } \\
\text { surgery if pregnancy or abnormalities of the reproductive system } \\
\text { were visualised or palpated. }\end{array}$ \\
\hline Sample size: & 108 dogs \\
\hline Intervention details: & $\begin{array}{l}\text { Dogs were randomly allocated to undergo OVE }(n=54) \text { or } \\
\text { OVH }(n=54) \text { via midline coeliotomy. } \\
\text { - A final year student was allocated to each case and given } \\
\text { written instructions of the procedure to be performed based } \\
\text { on a standard open protocol. } \\
\text { - The procedures were performed by the final year student } \\
\text { assigned to the case with a qualified veterinary surgeon } \\
\text { assisting, this assistant would complete the procedure if the } \\
\text { total surgical duration exceeded } 2 \text { hours or major } \\
\text { complications occurred. }\end{array}$ \\
\hline
\end{tabular}




\begin{tabular}{|c|c|}
\hline Study design: & Prospective, single centre, randomised, controlled, clinical trial \\
\hline Outcome studied: & $\begin{array}{l}\text { - Intra-operative complication rates. } \\
\text { - Time of surgery: } \\
\circ \text { from first incision to start of closure } \\
\circ \text { from start to end of closure } \\
\circ \text { total surgical time. } \\
\text { - Incision length. }\end{array}$ \\
\hline $\begin{array}{l}\text { Main findings: } \\
\text { (relevant to PICO question): }\end{array}$ & $\begin{array}{l}\text { - Two dogs in the OVH group experienced major } \\
\text { complications (one bladder laceration, one pedicle rupture } \\
\text { prior to ligation) which required the assistant veterinary } \\
\text { surgeon to complete the procedure, these were not } \\
\text { included in the final analysis. } \\
\text { - } 11 / 108 \text { cases exceeded the } 2 \text { hour time limit, } 8 / 51 \text { of the } \\
\text { OVH group and } 3 / 53 \text { of the OVE group - this was not } \\
\text { statistically significant. } \\
\text { - Mean total surgical time was } 88.7+/-20.6 \text { minutes in the } \\
\text { OVE group and } 92.0+/-27.6 \text { minutes in the OVH group. This } \\
\text { was not significantly different. } \\
\text { Mean incision length was } 8.7+/-2.6 \text { cm in the OVE group } \\
\text { and } 9.6+/-3.4 \text { cm in the OVH group. This was not } \\
\text { significantly different. } \\
\text { No significant difference was observed in time from first } \\
\text { incision to start of closure or time of closure between } \\
\text { groups. } \\
\text { Minor intra-operative complication rates occurred in } 12 / 52 \\
\text { (23\%) of the OVH group and } 21 / 54 \text { (39\%) of the OVE group - } \\
\text { this did not differ significantly between groups. }\end{array}$ \\
\hline Limitations: & $\begin{array}{l}\text { - This is a single centre study which may limit application to } \\
\text { other centres. } \\
\text { - Surgeries were performed by final year students and so } \\
\text { results may not be applicable to experienced veterinarians. } \\
\text { - Students may have been more familiar with OVH from time } \\
\text { in general practice where OVH is more commonly } \\
\text { performed. } \\
\text { - An assistant veterinary surgeon more experienced in OVH } \\
\text { was scrubbed in to procedures. } \\
\text { - Analgesia used is not recorded. } \\
\text { The text instructions supplied recommended a set incision } \\
\text { length with extension at the discretion of supervising } \\
\text { veterinary surgeon. } \\
\text { - Incision length was recorded as an absolute length rather } \\
\text { than as a proportion of the dog's length. } \\
\text { Different supervising veterinary surgeons of different skill } \\
\text { levels were assisting and this was not controlled between } \\
\text { groups. } \\
\text { There was no assessment of difference in skill levels of } \\
\text { students, this was likely to be variable and was not } \\
\text { controlled between groups. }\end{array}$ \\
\hline
\end{tabular}




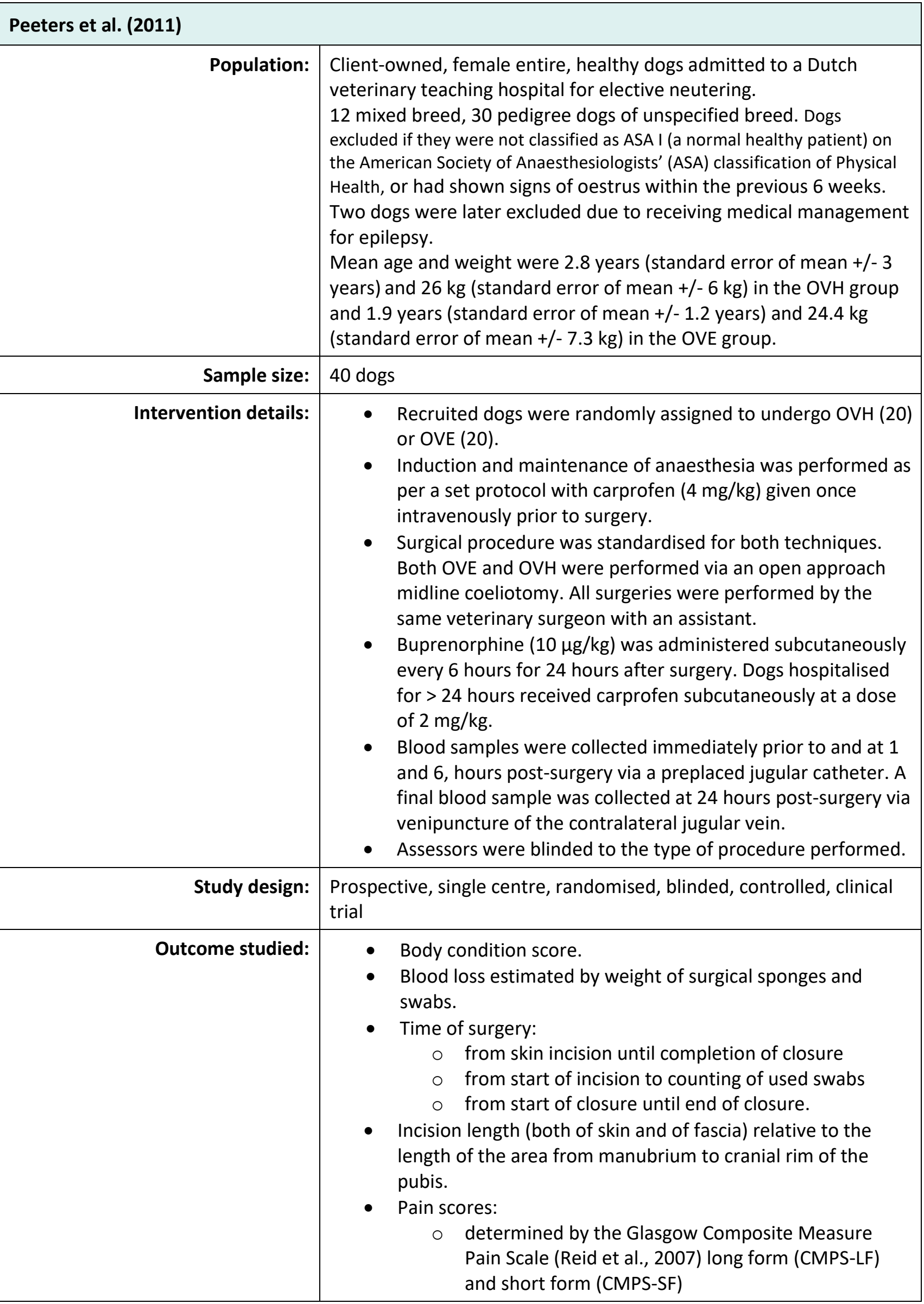




\begin{tabular}{|c|c|}
\hline & 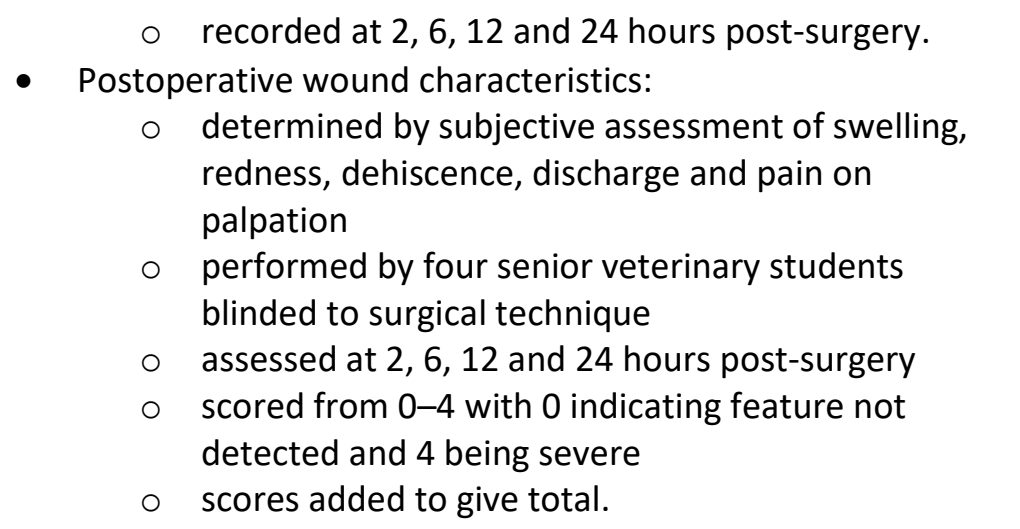 \\
\hline $\begin{array}{l}\text { Main findings: } \\
\text { (relevant to PICO question): }\end{array}$ & $\begin{array}{l}\text { The mean relative length of both the fascia and skin } \\
\text { incisions were significantly shorter in the OVE group ( } 17.7 \\
+/-1.8 \% \text { and } 19.8+/-2.0 \% \text { respectively) than in the OVH } \\
\text { group ( } 21.3+/-3.1 \% \text { and } 23.8+/-3.6 \% \text { respectively). } \\
\text { Surgical time (any component), postoperative pain and } \\
\text { wound scores at any time point were not significantly } \\
\text { different between groups. }\end{array}$ \\
\hline Limitations: & $\begin{array}{l}\text { - This is a single centre study which may limit application to } \\
\text { other centres. } \\
\text { - All procedures were performed by a single board certified } \\
\text { veterinary surgeon which may limit application to general } \\
\text { practice. } \\
\text { - Wound appearance was assessed by subjective methods. } \\
\text { - Collection of blood via a jugular catheter was performed at } 1 \\
\text { and } 6 \text { hours post-surgery, and by venipuncture at } 24 \text { hours } \\
\text { post-surgery, this may have affected pain scores. } \\
\text { - Incision length was determined by the operating veterinary } \\
\text { surgeon and may not reflect the required minimum incision } \\
\text { length for each procedure. } \\
\text { Dogs received buprenorphine analgesia at } 6 \text { hourly intervals } \\
\text { for } 24 \text { hours post-surgery. This is unlikely to reflect general } \\
\text { practice and may have hindered ability to detect differences } \\
\text { in pain scores between groups. }\end{array}$ \\
\hline
\end{tabular}

Tallant et al. (2016)

\begin{tabular}{|r|l|}
\hline Population: & $\begin{array}{l}\text { Adult, female entire dogs obtained from local humane society } \\
\text { shelters (country of origin not specified). Weight ranged from 3.3- } \\
\text { 30.1 kg. Dogs were excluded if there were signs of illness or } \\
\text { cardiovascular abnormalities, evidence of oestrus or pregnancy on } \\
\text { physical examination. }\end{array}$ \\
\hline Sample size: & 20 dogs \\
\hline Intervention details: & $\begin{array}{l}\text { Dogs were individually kenneled a minimum of } 24 \text { hours } \\
\text { prior to surgery. }\end{array}$ \\
& $\begin{array}{l}\text { Dogs were randomly assigned to receive either OVE or OVH. } \\
\text { Anaesthetic protocol was standardised with carprofen (4 } \\
\text { mg/kg) given once subcutaneously prior to surgery. }\end{array}$ \\
\hline
\end{tabular}




\begin{tabular}{|c|c|}
\hline & $\begin{array}{l}\text { - Surgery was performed as per a standardised technique via a } \\
\text { median coeliotomy. Haemostasis was achieved via a vessel } \\
\text { sealing device, this was also used to seal and divide the } \\
\text { uterine body where this was under } 9 \mathrm{~mm} \text {, where the uterine } \\
\text { body exceeded } 9 \mathrm{~mm} \text { a single circumferential ligature was } \\
\text { applied prior to transection. } \\
\text { - Aftercare was standardised. Rescue analgesia } \\
\text { (buprenorphine) was administered to dogs with pain scores } \\
\text { of } 5 / 24 \text { or greater. }\end{array}$ \\
\hline Study design: & Prospective, single centre, randomised, blinded clinical trial \\
\hline Outcome studied: & $\begin{array}{l}\text { - Total incision length. } \\
\text { - Duration of each phase of surgery: } \\
\circ \text { Phase 0: From induction to first incision } \\
\circ \text { Phase 1: From first incision to grasping the first ovary } \\
\circ \quad \text { Phase 2: From manipulation of the first ovary to } \\
\text { initiation of body wall closure } \\
\circ \quad \text { Phase 3: From initiation of body wall closure to } \\
\text { completion of skin closure. } \\
\text { - Heart rate, end-tidal isoflurane, systolic, mean and diastolic } \\
\text { blood pressure measured at each phase. } \\
\text { - Pain: } \quad \text { assessed at } 1,2,4,6,8,12,18 \text { and } 24 \text { hours after } \\
\text { surgery } \\
\circ \quad \text { performed by single blinded assessor } \\
\circ \quad \text { using the CMPS-SF and a } 10 \mathrm{~cm} \text { visual analog scale } \\
\circ \quad \text { wound sensitivity was measured using an algometer } \\
\text { with readings given in Newtons; } \\
\text { for each time point three readings were } \\
\text { obtained from a point } 1 \mathrm{~cm} \text { cranial to the } \\
\text { cranial edge of the incision. }\end{array}$ \\
\hline $\begin{array}{l}\text { Main findings: } \\
\text { (relevant to PICO question): }\end{array}$ & $\begin{array}{l}\text { - The change in mean arterial pressure between phase } 1 \text { and } \\
2 \text { was greater in the OVH group (increase of } 25+/-14 \\
\mathrm{mmHg} \text { ) than the OVE group (increase of } 9+/-15 \mathrm{mmHg} \text { ). } \\
\text { - The change in diastolic pressure between phase } 1 \mathrm{and} 2 \text { was } \\
\text { greater in the OVH group (increase of } 27+/-13 \mathrm{mmHg} \text { ) than } \\
\text { the OVE group (increase of } 6+/-14 \mathrm{mmHg} \text { ). } \\
\text { - There were no significant differences between groups in } \\
\text { blood pressure between other phases, or heart rate and } \\
\text { systolic pressure changes between any phases. } \\
\text { - The mean heart rate of the OVE group was significantly } \\
\text { greater than that of the OVH group during phase } 0 \text { and } \\
\text { during phase } 3 \text {. } \\
\text { The end-tidal isoflurane was significantly lower for the OVH } \\
\text { group compared to the OVE group during phase } 1 \text { and phase } \\
2 . \text { There was no difference during phase } 3 \text { or between the } \\
\text { phases. } \\
\text { Mean procedure time was significantly greater for the OVH } \\
\text { group ( } 17.5+/-2.4 \text { minutes) compared to the OVE group } \\
\text { (15.4 }+/-1.7 \text { minutes). There were no significant differences }\end{array}$ \\
\hline
\end{tabular}




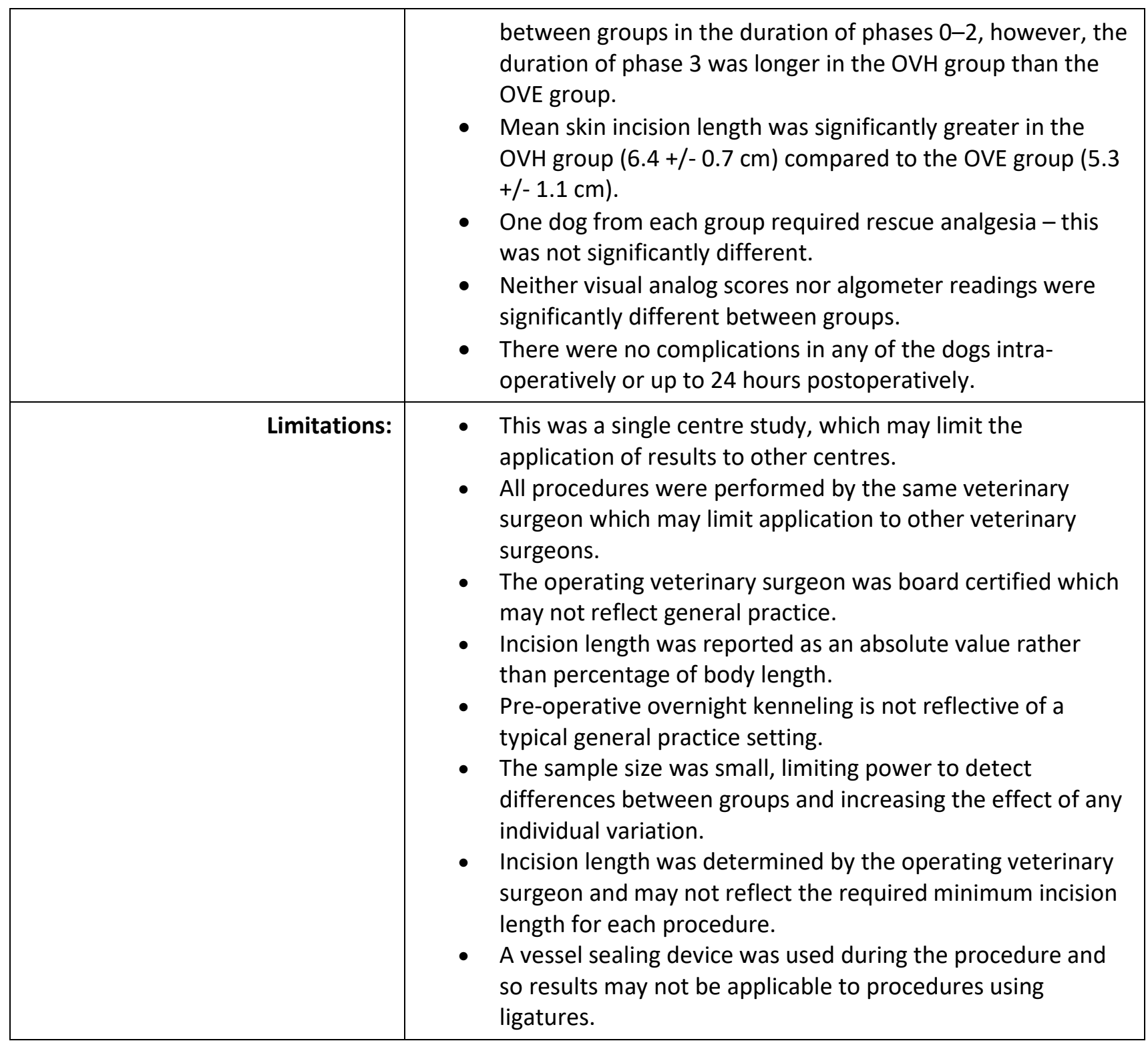

\begin{tabular}{|r|l|}
\hline \multicolumn{2}{|l|}{ Lee et al. (2013) } \\
\hline Population: & $\begin{array}{l}\text { Female entire, purpose-bred, crossbreed dogs (country of origin not } \\
\text { specified). } \\
\text { Dogs were excluded if abnormalities were found on clinical } \\
\text { examination or serum biochemical profile/complete blood count } 24 \\
\text { hours prior to surgery. }\end{array}$ \\
\hline Sample size: & 13 dogs \\
\hline Intervention details: & $\begin{array}{l}\text { Dogs were kenneled } 24 \text { hours prior to surgery. } \\
\text { - Anaesthetic protocol was standardised. }\end{array}$ \\
& $\begin{array}{l}\text { All surgeries were performed in the morning by a single } \\
\text { experienced veterinary surgeon. OVE (6 dogs) or OVH (7 } \\
\text { dogs) were performed as per a standardised technique via } \\
\text { midline celiotomy. }\end{array}$ \\
\hline
\end{tabular}




\begin{tabular}{|c|c|}
\hline & $\begin{array}{l}\text { - Butorphanol }(0.4 \mathrm{mg} / \mathrm{kg}) \text { was administered intravenously } \\
\text { prior to extubation, no further analgesia was given. } \\
\text { - Blood sampling was performed by jugular venipuncture prior } \\
\text { to surgery then at } 1,2,4,6,12 \text { and } 24 \text { hours post-surgery. } \\
\text { - Aftercare was standardised. }\end{array}$ \\
\hline Study design: & Prospective, single centre clinical trial \\
\hline Outcome studied: & $\begin{array}{l}\text { - Pain assessment: } \\
\circ \text { performed by blinded assessor } \\
\circ \text { using short form of the Glasgow Composite Measure } \\
\text { Pain Scale (CMPS-SF) (Reid et al., 2007) } \\
\circ \quad \text { assessed prior to surgery then at 1, 2, 4, 6, } 12 \text { and } 24 \\
\text { hours post-surgery. } \\
\text { - Serum cortisol and glucose } \\
\quad \text { assessed prior to surgery then at 1, 2, 4, 6, } 12 \text { and } 24 \\
\quad \text { hours post-surgery. } \\
\text { - Incision length. } \\
\text { - Surgical duration. } \\
\text { - Anaesthetic duration. } \\
\text { - Intra and postoperative complications. }\end{array}$ \\
\hline $\begin{array}{l}\text { Main findings: } \\
\text { (relevant to PICO question): }\end{array}$ & $\begin{array}{l}\text { - No complications were observed intra or postoperatively in } \\
\text { either group. } \\
\text { - Incision length was significantly shorter in the OVE group. } \\
\text { Mean incision length was } 10.1+/-2.2 \mathrm{~cm} \text { in the OVH group } \\
\text { and } 4.4+/-0.3 \mathrm{~cm} \text { in the OVE group. } \\
\text { - Surgical duration was significantly shorter in the OVE group. } \\
\text { Mean surgical time was } 52.3+/-2.1 \text { minutes in the OVH } \\
\text { group and } 35.8+/-2.8 \text { minutes in the OVE group. } \\
\text { - Anaesthetic duration was significantly shorter in the OVE } \\
\text { group. Mean anaesthetic time was } 66.1+/-4.4 \text { minutes in } \\
\text { the OVH group and } 47.1+/-4.0 \text { minutes in the OVE group. } \\
\text { - The OVE group had a significantly lower CMPS-SF score than } \\
\text { the OVH group at } 1,2,4 \text { and } 6 \text { hours postoperatively. } \\
\text { - Serum cortisol and glucose values did not differ significantly } \\
\text { between groups. }\end{array}$ \\
\hline Limitations: & $\begin{array}{l}\text { - This was a single centre study which may limit application of } \\
\text { results to other centres. } \\
\text { - All procedures were performed by the same veterinary } \\
\text { surgeon which may limit application to other veterinary } \\
\text { surgeons. } \\
\text { - Venipuncture was performed regularly throughout the study } \\
\text { which may have affected pain scores. } \\
\text { - Incision length was reported as an absolute value rather } \\
\text { than percentage of body length. } \\
\text { - The study population were purpose bred crossbreeds which } \\
\text { may limit application to other breeds. } \\
\text { - Pre-operative overnight kenneling is not reflective of a } \\
\text { typical general practice setting. } \\
\text { The sample size was small, limiting power to detect } \\
\text { differences between groups and increasing the effect of any } \\
\text { individual variation. }\end{array}$ \\
\hline
\end{tabular}




\begin{tabular}{|l|l|}
\hline - & $\begin{array}{l}\text { Incision length was determined by the operating veterinary } \\
\text { surgeon and may not reflect the required minimum incision } \\
\text { length for each procedure. }\end{array}$ \\
- & Dogs received one injection of butorphanol analgesia \\
postoperatively only. This was in contrast to other studies \\
where a non-steroidal anti-inflammatory drug (NSAID) was \\
administered which may be more typical of general practice. \\
This may account for the differences in pain score noted. \\
\hline
\end{tabular}

Okkens et al. (1997)

\begin{tabular}{|c|c|}
\hline Population: & $\begin{array}{l}\text { Female dogs of various breeds which had undergone either an OVE } \\
\text { or OVH procedure at a Dutch, teaching hospital } 8-11 \text { years prior to } \\
\text { the study. Weight range at time of surgery } 1.6-37.5 \mathrm{~kg} \text {, age range at } \\
\text { time of surgery } 9.6 \text { months to } 9 \text { years. }\end{array}$ \\
\hline Sample size: & 135 dogs \\
\hline Intervention details: & $\begin{array}{l}\text { Dogs had been randomly selected to receive either OVH } \\
\text { ( } n=66) \text { or OVE ( } n=69) \text {. Anaesthesia and surgical technique } \\
\text { were standardised. } \\
\text { A questionnaire was sent to owners } 8-11 \text { years post-surgery. } \\
\text { Questions included whether the dog had experienced } \\
\text { abdominal pain, vaginal discharge, endometritis/pyometra } \\
\text { attractiveness to male dogs and urinary incontinence post- } \\
\text { surgery. If any of the questions were answered positively a } \\
\text { follow-up phone call was carried out. }\end{array}$ \\
\hline Study design: & Retrospective single centre, cohort study \\
\hline Outcome studied: & $\begin{array}{l}\text { Incidence of urinary incontinence, ovarian remnant syndrome, } \\
\text { attractiveness to male dogs, abdominal pain, vaginal discharge, } \\
\text { endometritis/pyometra post-surgery. }\end{array}$ \\
\hline $\begin{array}{l}\text { Main findings: } \\
\text { (relevant to PICO question): }\end{array}$ & $\begin{array}{l}\text { - No attractiveness to male dogs or abdominal pain as a } \\
\text { consequence of elective neutering was reported in any dog. } \\
\text { - Asymptomatic vaginal discharge was observed in two dogs } \\
\text { from either group. } \\
\text { - Six dogs in the OVE group and nine in the OVH group } \\
\text { developed urinary incontinence. } \\
\text { - There was no incidence of endometritis/pyometra in either } \\
\text { group. } \\
\text { - There was no significant difference between groups in the } \\
\text { incidence of any of the urogenital problems studied during } \\
\text { the follow-up period. }\end{array}$ \\
\hline Limitations: & $\begin{array}{l}\text { - The method of randomisation was not reported and thus } \\
\text { cannot be critiqued. } \\
\text { - The questions asked were not reported and it is not clear if } \\
\text { these may have biased client answers. } \\
\text { - The study is retrospective and follow-up was performed. } \\
\text { - Group matching (of age, weight etc.) was not possible and } \\
\text { therefore confounding factors may have influenced results. }\end{array}$ \\
\hline
\end{tabular}




\begin{tabular}{|l|l|}
\hline - The study may be underpowered to detect differences in the \\
rate of urinary incontinence between groups due to the \\
relatively uncommon nature of the condition. \\
- $\begin{array}{l}\text { Due to the long follow-up time, accuracy of client } \\
\text { recollection would be expected to have reduced. }\end{array}$ \\
- The level of experience of the veterinary surgeons \\
performing the procedures is not reported. \\
Bias may have been introduced by cases with negative \\
outcomes being less likely to have complete case records \\
and therefore being more likely to be excluded.
\end{tabular}

\section{Appraisal, application and reflection}

Five papers were found to be relevant to this knowledge summary, four prospective clinical trials (Peeters et al., 2011; Lee at al., 2013, Harris et al., 2013; and Tallant et al., 2016) and a retrospective cohort study (Okkens et al., 1997).

The retrospective cohort study (Okkens et al., 1997) reviewed long-term complications post OVE and OVH and found no occurrence of pyometra/endometritis in 135 dogs 8-11 year post-surgery. This finding is anticipated as pyometra is known to occur secondary to cystic endometrial hyperplasia; a disorder which requires the presence of progesterone and would not be expected to occur in the absence of functional ovarian tissue or administration of exogenous hormones (De Tora \& McCarthy, 2011). Likewise the group reported there was no significant difference in urinary incontinence between groups. The findings of this study must be considered with caution however, as there may be some inherent bias with dissatisfied owners less likely to provide follow-up and therefore to be included.

Harris et al. (2013), a prospective, randomised clinical trial, prospectively monitored OVE and OVH surgeries performed by final year vet students. This study found no difference in incision length, surgical time or incidence of intra-operative complications between techniques; however the relevance of this study to procedures performed by qualified veterinarians experienced in routine neutering is disputable.

The remaining papers all evaluated surgeries performed by experienced veterinarians. These studies all compared incision length, surgical time and postoperative pain between groups. All found mean incision length was shorter in the OVE group and two (Lee et al., 2013; and Tallant et al., 2016) found that surgical duration was shorter in the OVE group; however the clinical impact of these findings is not clear as the reduction in both parameters was small. Additionally it should be noted that the surgeries reported by Tallant et al. (2016) were performed with the aid of a vessel sealing device, therefore results may not be applicable to procedures performed with suture ligation.

Differences in pain scores reported by these papers are harder to interpret. Only one paper (Lee et al., 2013), found a significant difference in pain scoring between groups; with the OVE group having lower scores at 1, 2, 4 and 6 hours post-surgery. However this was a small study $(n=13)$ with purpose-bred dogs and procedures performed by a single veterinary surgeon. Equally two of the three groups (Peeters et al., 2011; and Lee et al., 2013) also performed postoperative blood sampling at regular intervals which may have affected pain score accuracy. Finally analgesia protocol varied between papers. Pre-operative NSAID administration was performed by Tallant et al. (2016) and Peeters et al. (2011), but not by Lee et al. (2013). Tallant et al. (2016) administered buprenorphine at 6 hourly intervals for 24 hours post-surgery, whilst Peeters et al. (2011) only included this as a rescue protocol and Lee et al. (2013) administered a single butorphanol injection only. Administration of additional analgesia beyond what is commonly used in general practice may hinder ability to detect differences in pain scores between groups, however withholding analgesia that is commonly used, may artificially increase differences in groups beyond what would be anticipated. 
Lee et al. (2013) and Tallant et al. (2016) also recorded intra-operative complications, however none were noted in either group.

Gonadectomy in female dogs is generally performed to prevent misalliance and pyometra, for behavioural reasons and to reduce the risk of mammary and uterine neoplasia. Removal of the ovaries alone would be expected to prevent unwanted pregnancy, pyometra and to have an equal impact on the risk of mammary neoplasia as $\mathrm{OVH}$, due to the cessation of ovarian hormone production. The effect of leaving the uterus in situ on the development of uterine neoplasia has not been evaluated, however as this disease is rare - the incidence of canine malignant uterine neoplasia is approximately $0.003 \%$ (Van Goetham et al., 2006) - and anticipated to be at least in part hormonally mediated, the impact of a change in practice from OVE to OVH on the uterine neoplasia related morbidity/mortality is likely to be negligible.

Of the studies reviewed here only two major complications were reported, both by Harris et al. (2013). Of these complications one, bladder laceration, would be expected to occur more commonly in OVH procedures due to the more caudal placement of the distal ligature. However, this study did not find a significant difference in complications between groups overall. It has also been proposed that OVE may be associated with a reduced risk of ureteral ligation; as the distal ureter is located caudal to the placement of the distal ovarian ligatures in OVE, but in the vicinity of the uterine ligature when an OVH is performed (De Tora \& McCarthy, 2011). However serious complications secondary to neutering are rare and there is currently no evidence showing a difference in perioperative complications between techniques.

This knowledge summary reviewed surgery performed via a midline coeliotomy incision only, surgery performed via flank incision was not considered as part of this knowledge summary and data may not necessarily be extrapolated to other approaches.

In conclusion though the evidence reviewed within this knowledge summary suggests that OVE may be associated with shorter surgical duration and incision length than OVH there are several major weaknesses which prevent definitive conclusions. Firstly, where significant results are reported actual differences are not large and may be clinically insignificant. Secondly, all but two of the papers (Okkens et al. 1997; and Harris et al., 2013) used sample sizes of 40 or fewer animals, thus confounding factors are more likely to affect results and extrapolation to a general population becomes more challenging. Of the two papers which did use larger sample sizes, one (Harris et al. 2016) reviewed surgeries performed by final year students; consequently the implication of results from unqualified vets is not clear; and the second was a retrospective study reviewing owner reported long-term complications only. Finally, the population and techniques used between studies varied markedly and were often not representative of UK general practice; for example Lee et al. (2013) used only purpose-bred cross breed dogs, Tallant et al. (2016) used vessel-sealing devices rather than suture ligation, and Peeters et al. (2011) regularly blood sampled patients to collect data for a separate study.

No difference in complication rates between groups has been shown and differences in postoperative pain scores between procedures have not been convincingly demonstrated. No papers identified an advantage of performing OVH over OVE. These results apply only to animals with grossly normal uteri at coeliotomy, and hysterectomy is still recommended when uterine pathology is present.

Further indicated research includes large scale studies allowing identification of differences in rare intraoperative complications and randomised, clinical trials in larger numbers of animals in a setting more reflective of general practice, to determine if a significant difference between procedures is found when power is increased. 


\begin{tabular}{|c|c|}
\hline & \\
\hline $\begin{array}{r}\text { Databases searched and dates } \\
\text { covered: }\end{array}$ & $\begin{array}{l}\text { CAB Abstracts on OVID Platform } 1973 \text { to } 2019 \text { Week } 08 \\
\text { PubMed accessed via the NCBI website (1910-2019) }\end{array}$ \\
\hline Search terms: & 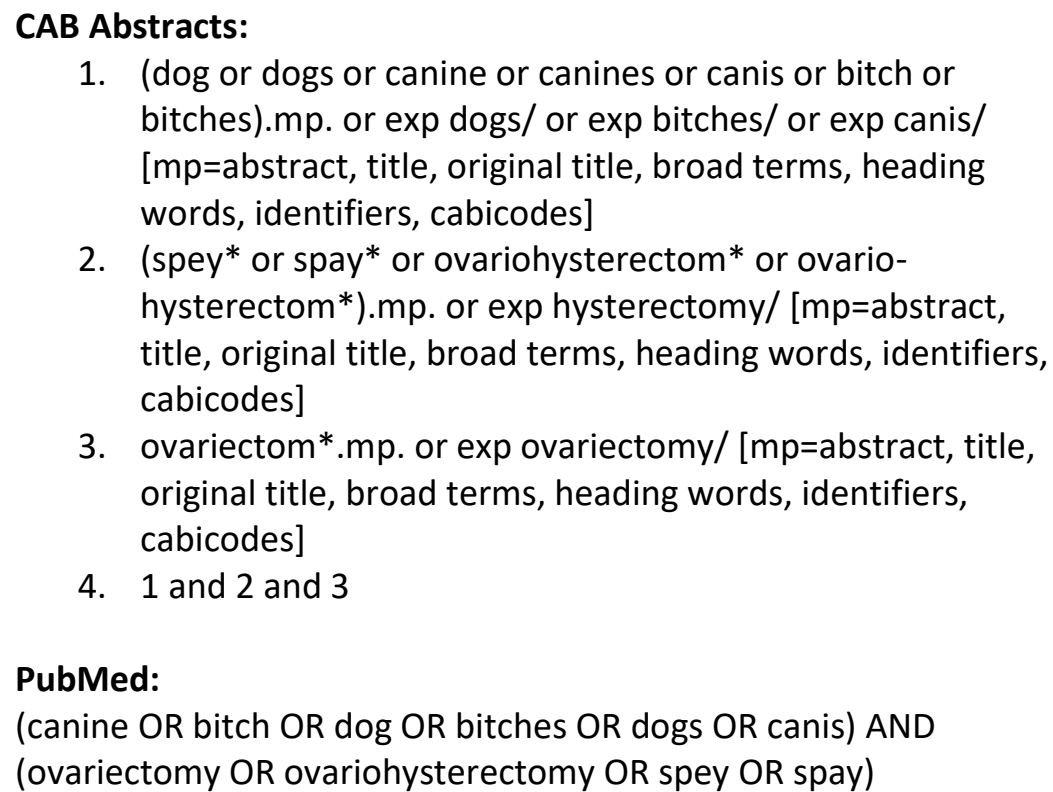 \\
\hline Dates searches performed: & $\begin{array}{l}\text { CAB Abstracts: 07/03/19 } \\
\text { PubMed: } 12 / 03 / 19\end{array}$ \\
\hline
\end{tabular}

\section{Exclusion / Inclusion Criteria}

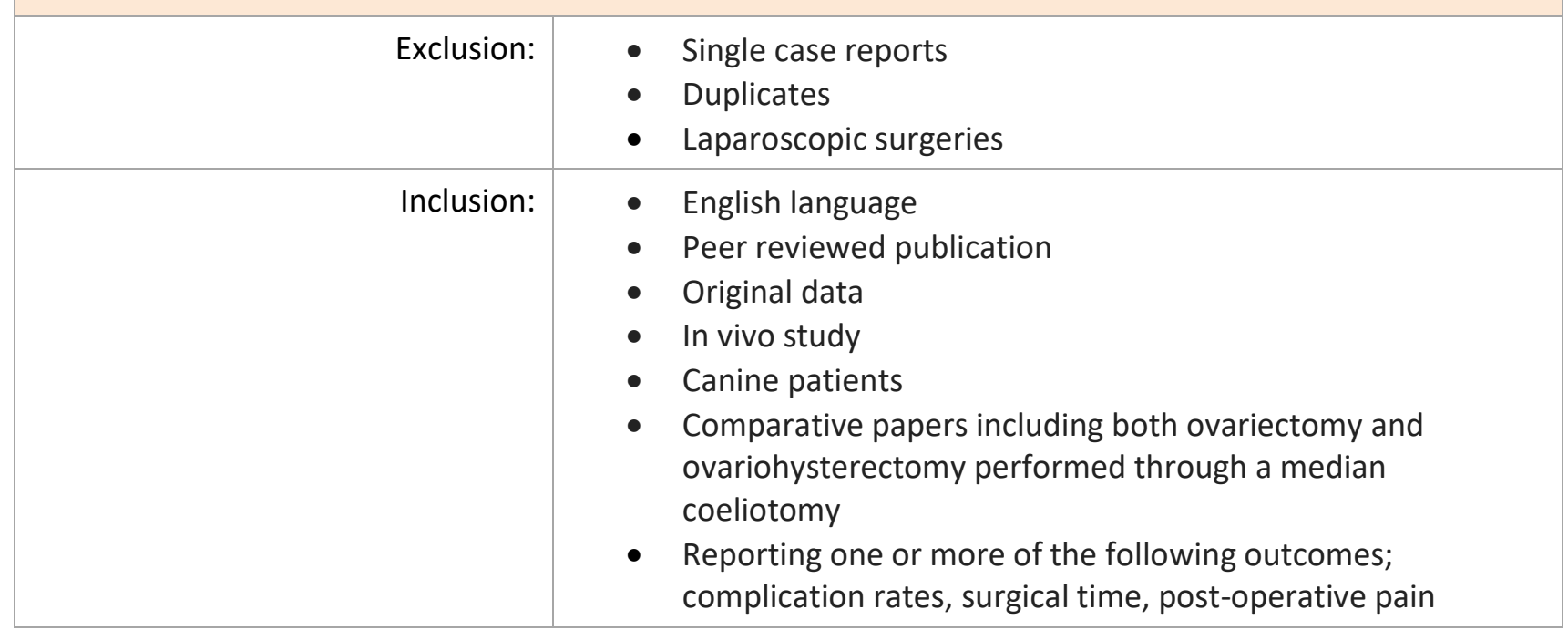




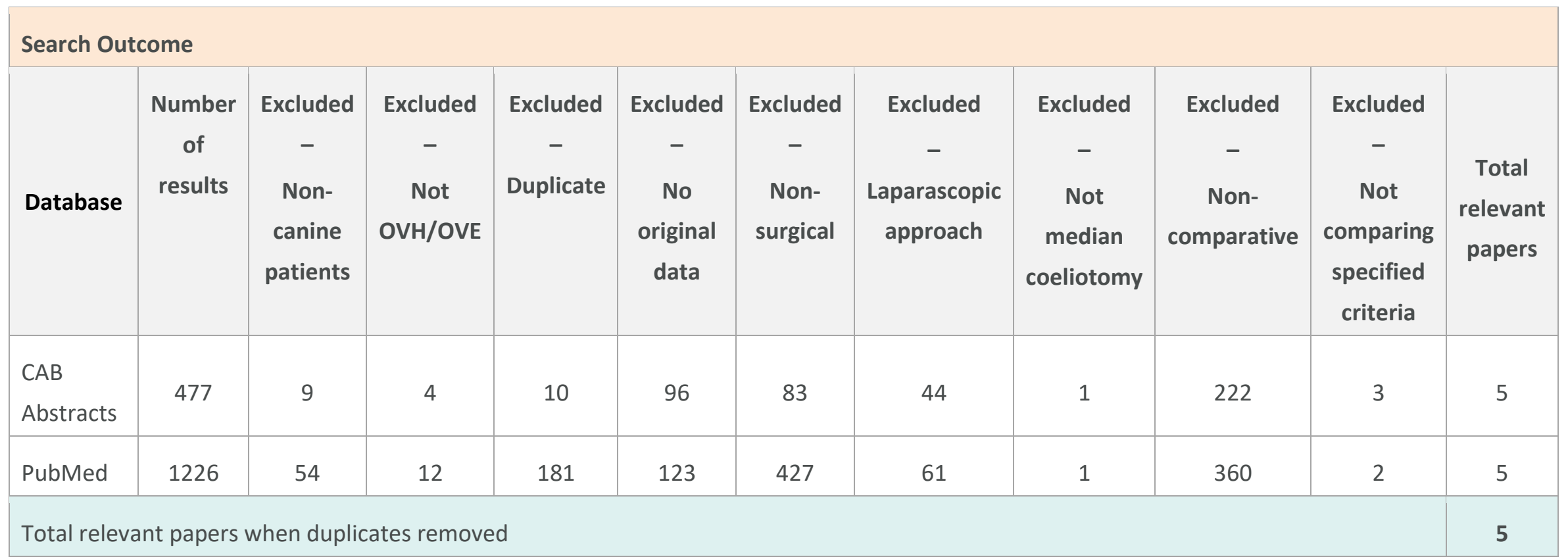

Vol 5, Issue 2

DOI: 10.18849/VE.V5I2.303 


\section{CONFLICT OF INTEREST}

The authors declare no conflict of interest.

\section{REFERENCES}

1. American Society of Anesthesiologists. (1963). New classification of physical status. Anesthesiology. 24:111.

2. DeTora, M. \& McCarthy, R. (2011). Ovariohysterectomy versus ovariectomy for elective sterilization of female dogs and cats: is removal of the uterus necessary? Journal of the American Veterinary Medical Association. 239(11):1409-1412. DOI: http://dx.doi.org/10.2460/javma.239.11.1409

3. Harris, K., Adams, V., Fordyce, P. \& Ladlow, J. (2013). Comparison of surgical duration of canine ovariectomy and ovariohysterectomy in a veterinary teaching hospital. Journal of Small Animal Practice. 54(11):579-583. DOI: https://doi.org/10.1111/jsap.12147

4. Lee, S., Lee, S., Park, S., Kim, Y., Seok, S., Hwang, J., Lee, H. \& Yeon, S. (2013). Comparision of Ovariectomy and Ovariohysterectomy in terms of postoperative pain behavior and surgical stress in dogs. Journal of Veterinary Clinics. 30(3):166-171.

5. Okkens, A.C., Kooistra, H.S. \& Nickel, R.F. (1997). Comparison of long-term effects of ovariectomy versus ovariohysterectomy in bitches. Journal of Reproduction and Fertility Supplement. 51:227-31 Peeters, M.E. \& Kirpensteijn, J. (2011). Comparison of surgical variables and short-term postoperative complications in healthy dogs undergoing ovariohysterectomy or ovariectomy. Journal of the American Veterinary Medical Association. 238:189-94. DOI: http://dx.doi.org/10.2460/javma.238.2.189

6. Reid, G., Nolan, A., Hughes, J., Lascelles, D., Pawson, P. \& Scott, E. (2007). Development of the shortform Glasgow Composite Measure Pain Scale (CMPS-SF) and derivation of an analgesic intervention score. Animal Welfare, 16(S):97-104.

7. Tallant, A., Ambros, B., Freire, C. \& Sakals, S. (2016). Comparison of intraoperative and postoperative pain during canine ovariohysterectomy and ovariectomy. The Canadian Veterinary Journal. 57(7):741746.

8. Van Goethem, B., Schaefers-Okkens, A. \& Kirpensteijn, J. (2006). Making a rational choice between ovariectomy and ovariohysterectomy in the dog: a discussion of the benefits of either technique. Veterinary Surgery. 35(2):136-143. DOI: http://dx.doi.org/10.1111/j.1532950X.2006.00124.x 


\section{EVIIDEFeE

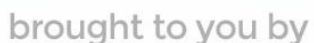 \\ RCVS KNOWLEDGE}

\section{Intellectual Property Rights}

Authors of Knowledge Summaries submitted to RCVS Knowledge for publication will retain copyright in their work, and will be required to grant RCVS Knowledge a non-exclusive license of the rights of copyright in the materials including but not limited to the right to publish, re-

publish, transmit, sell, distribute and otherwise use the materials in all languages and all media throughout the world, and to license or permit others to do so.

\section{Disclaimer}

Knowledge Summaries are a peer-reviewed article type which aims to answer a clinical question based on the best available current evidence. It does not override the responsibility

of the practitioner. Informed decisions should be made by considering such factors as individual clinical expertise and judgement along with patient's circumstances and owners' values. Knowledge Summaries are a resource to help inform and any opinions expressed within the Knowledge Summaries are the author's own and do not necessarily reflect the view of the RCVS Knowledge. Authors are responsible for the accuracy of the content. While the

Editor and Publisher believe that all content herein are in accord with current recommendations and practice at the time of publication, they accept no legal responsibility

for any errors or omissions, and make no warranty, express or implied, with respect to material contained within.

For further information please refer to our Terms of Use.

RCVS Knowledge is the independent charity associated with the Royal College of Veterinary Surgeons (RCVS). Our ambition is to become a global intermediary for evidence based veterinary knowledge by providing access to information

that is of immediate value to practicing veterinary professionals and directly contributes to evidence based clinical decision-making.

https://www.veterinaryevidence.org/

RCVS Knowledge is a registered Charity No. 230886.

Registered as a Company limited by guarantee in England and Wales No. 598443.

Registered Office: Belgravia House, 62-64 Horseferry Road, London SW1P 2AF

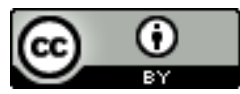

This work is licensed under a Creative Commons Attribution 4.0 International License 